\title{
A FÉNYKÉPEZÉS KUTATÁSMÓDSZERTANI FELHASZNÁLÁSÁNAK LEHETŐSÉGEI A PEDAGÓGIÁBAN
}

\section{TORGYIK JUDIT}

\author{
a Kodolányi János Főiskola Neveléstudományi Tanszék \\ föiskolai tanára \\ jtorgyik@uranos.kodolanyi.hu
}

Nemrégiben új, figyelemfelkeltő szakkönyv jelent meg a könyvpiacon, a lengyel Piotr Sztompka (2009) tollából, Vizuális szociológia. A fényképezés mint kutatási módszer címmel. Noha a kötet a szerző eredeti szándéka szerint szociológusoknak készült, azonban jó szívvel ajánlható a neveléstudománnyal ismerkedő hallgatók és a pedagógiát tanítók, illetve a szélesebb értelemben vett társadalomtudománnyal foglalkozók számára is. A kiadvány remekül kiegészíti kutatás-módszertani ismereteket, megvilágítja a vizuális információ-szerzés és elemzés lehetőségeit, melyeket alkotó módon továbbgondolva pedagógiai témájú vizsgálatoknál, összehasonlító jellegü, iskolai megfigyeléseknél, tartalomelemzés és interjúkészítés során egyaránt sikerrel lehet használni. A kötet szerzője számos olyan példát ad, amelyek kiválóan alkalmazhatók a tanár és tanítójelöltek képzésében, és általában véve az élményszerü oktatásra vágyók körében.

Sztompka hat fejezetben mutatja be a fényképezés nagyszerü felhasználási lehetőségeit a társadalomtudományokban. Kiindulópontként az első két fejezetben arra világít rá, hogy a környezetben rejlő vizuális információk megfigyelése, célirányos megfejtése érzékenyebbé teszi a szemlélőt a körülötte lévő világ normái, értékei, kulturális felépítésének nyíltan és rejtetten megbújó mondanivalója irányt. A XXI. században mind több a bennünket körülvevő vizuális jel, különösen így van ez a nagyvárosokban, ahol a reklámok, az óriásplakátok, a graffitik rengetege tarkítja a köztereket, s már-már vizuális korszakváltásról lehet beszélni. A fényképezés a társadalomtudományi kutatás egyik régen ismert módszere, a fényképező személy, pedig lencsevégre kaphat oktatási, nevelési, gyerekekkel összefüggő tartalmakat is.

Szakdolgozatok készítésekor, szemináriumi dolgozat írásakor, iskolalátogatások alkalmával nem ritkán része a hallgatói feladatoknak fényképek készítése is. Az így létrejött fotók sokféle, változatos szempont mentén elemezhetök, erre mutat rá a könyv harmadik része. A rögzített anyag elemzése történhet az idődimenziót alapul véve (milyen volt régen, s mi jellemző ma?), a különböző kultúrákat összehasonlítva (mi jellemző az egyik, mi a másik kultúrában?), valamint a fényképen látható tartalmakból kiindulva is. A szerző számos konkrét, praktikus szempontot ír le arra vo- 
natkozóan, hogyan elemezhető a képen lévő ember, a cselekvés, az interakció, a közösség és a kultúra, valamint a társadalmi környezet az egyes vizsgálatok során. Felhívja figyelmünket arra is, hogy nem csupán magát a képet érdemes szemlélnünk és elemeznünk, hanem a kép készítőjének szándékait, szubjektív, egyedi indítékait, valamint a képen szereplők fotózásra adott beszédes reakcióját is. A kép készítőjét minden esetben sajátosan egyéni szempontok vezérlik, melyek nagyban befolyásolják, mit fog észrevenni, mit fog fókuszba állítani munkája során.

A könyv módszertani szempontból egyik legértékesebb része az a fejezet, amelyben a fényképezés, mint más kutatási módszerek kiegészítése, együttes alkalmazásának hogyanja kerül ismertetésre. A szerző a könyv negyedik fejezetében bemutatja, milyen módon lehet a fotózás a megfigyelés segítője, a tartalomelemzés célpontja, vagy az interjúzás remek kiegészítő kelléke.

Fényképeket a társadalomtudományokban már az első egzotikus tájakra utazó antropológusok is készítettek, akik terepkutatásaik során használták a masinát. Emlékezetes Margaret Mead és munkatársa, Gregory Bateson Bali karakter címü fotósorozata, melynek fö célja az 1930-as években, Bali-szigetén élő őslakosok szocializációjának, szülő-gyerek kapcsolatának jellegzetes megfigyelésére irányuló vizsgálata volt. A kutatók azt szerették volna érzékletesen demonstrálni, hogyan alakul a szigetlakók élete, személyisége, melynek érdekében több száz fényképet készítettek, majd aztán szöveggel láttak el, s a fényképek és annak kiegészítő szövege mind az antropológia, mint pedig a neveléstudomány számára a mai napig gazdag anyagot szolgáltat e távoli kultúra mindennapi életéröl, az ott élők világáról és nevelési jellegzetességeiről. Iskolalátogatások, alternatív iskolák, hazai és külföldi oktatási intézmények megismerésekor nem egyszer elökerül a fényképezőgép nálunk is, s az így készített fotók ugyancsak használható alapanyagot adnak a tanulás, a tanítás során.

A fénykép azonban nem csak a megfigyelés eszköze, hanem a tartalomelemzés tárgya is lehet. A legtöbb tartalomelemzéssel kapcsolatos módszertani szakkönyv szövegek elemzéséről szól, s csupán mintegy mellékesen említi, hogy képeket, rajzokat, vizuális tartalmakat szintén lehet ily módon vizsgálni. Ebben a könyvben azonban gazdag ötlettárat kapunk ahhoz, hogyan jó mindezt megoldani, milyen módon lehet a tartalomelemzést vizuális anyagokon szakszerủen elvégezni. A felvetés kiváló alkalom arra, hogy neveléstudománnyal kapcsolatos témákat is górcső alá vegyünk. Régi iskolai fényképek, tankönyvek képanyaga, gyermekek világát bemutató újságcikkek illusztrációi, régen kiadott könyvek fotói pompásan tükrözik az adott kor szellemének jellegzetességeit. A képek alkalmasak dokumentumelemzésre is, és az interjúk segédeszközeként ugyancsak felhasználhatók. Jól ismert a kutatók körében az ún. fotóinterjú, vagy más néven interjú fotóinterpretációval, mely arról szól, hogy az interjú során a kikérdezett személy kap egy képet, s megkérjük, mondja el, ami az eszébe jut róla. A cél az, hogy a vizsgálati személyt minél jobban megnyissuk, a képpel kapcsolatban minél részletesebben kikérdezzük. 
Sajátos formája a fotóinterjúnak, amikor a vizsgálat alanyáról készített képröl folyik a beszélgetés, ilyenkor megismerhetô a kikérdezett véleménye, feltárható személyiségére irányuló önreflexiójának tartalma. A fotóinterjú fókuszcsoportos kikérdezés során is hasznosítható - nem csak a szociológiában.

Az autofotográfiára ad érdekes példát a szerző, amikor arról szól, hogy Lengyelországban a rendszerváltás után, 10-17 év közötti, hátrányos helyzetü gyerekeknek és fiataloknak adtak masinákat, hogy egy hétig tetszésük szerint készítsenek képeket. Az így létrejött több ezer mü a gyerekek barátairól, közvetlen környezetéröl, játékairól éles szemmel mutatta be az akkori, nehéz helyzetben lévő ország jellemzőit, olyannyira, hogy népszerü kiállítást is szerveztek belőle.

Az ötödik, a fénykép mint az interpretáció tárgya címmel írt fejezet, azt veszi sorra, milyen jellegủ elemzésnek vethetjük alá a fényképeket a kutatás során. Más lesz az eredmény, ha a hermeneutikai, a szemiológiai, a strukturalista, vagy ha a diszkurzív interpretációt választjuk. Sztompka részletesen bemutatja az egyes elemzési lehetőségek jellemzőit, mely leírások a pedagógiával ismerkedök számára tanulmányaik során ugyancsak hasznosak.

A hatodik részben a szerző végigveszi azokat a közkedvelt társadalomtudományi irányzatokat, amelyek rendszerébe akadálytalanul beilleszthető a fényképezés. A fenomenológiától kezdve az etnometodológián át a dramaturgiai elmélet magyarázatával egyaránt leírható a fényképezés helye a társadalomtudományok rendszerében. Szinte minden klasszikus elméletbe beilleszthető a képi elemzés.

Végül, de nem utolsó sorban a könyv melléklete az oktatóknak nyújt didaktikai példatárat arról, hogyan használhatjuk a társadalomtudomány iránt érdeklődő hallgatókkal való foglalkozásban a fényképeket, a szemináriumok és a gyakorlati órákon milyen alkalmak nyílnak fotók elemzésére.

Úgy vélem, hogy a kötet olvasása után újragondolhatjuk a vizuális kultúra neveléstudományi felhasználását, melynek során értékes, interdiszciplináris, módszertani megoldások születhetnek a felsőoktatásban müködők körében. Már csak azért is, mert az emberek egy része tanulási stílusát tekintve vizuális típus, $\mathrm{s}$ a többség fogékony a képi információk iránt. A fénykép nem egyszerüen egy-egy szakdolgozat, szemináriumi dolgozat illusztrálására szolgál, hanem módszerként használva jó eszköz arra is, hogy élesebben lássuk a bennünket körülvevő környezet jelzéseit, $\mathrm{s}$ egyúttal többet megértsünk a társadalom neveléssel kapcsolatos dimenziójának értékrendszeréböl, sokszor tudattalanul is jelen lévő üzenetéböl.

Sztompka, Piotr (2009): Vizuális szociológia. A fényképezés mint kutatási módszer. Gondolat Kiadó, PTE Kommunikáció-és Médiatudományi Tanszék, Budapest-Pécs, 212 oldal. 